\title{
The 2017 North Bay and Southern California Fires: A Case Study
}

\author{
Nicholas J. Nauslar ${ }^{1,2, *(\mathbb{D})}$, John T. Abatzoglou ${ }^{3}$ (i) and Patrick T. Marsh ${ }^{2}$ \\ 1 Cooperative Institute for Mesoscale Meteorological Studies, University of Oklahoma, \\ Norman, OK 73072, USA \\ 2 NOAA/NWS/NCEP Storm Prediction Center, Norman, OK 73072, USA; patrick.marsh@noaa.gov \\ 3 Department of Geography, University of Idaho, Moscow, ID 83844, USA; jabatzoglou@uidaho.edu \\ * Correspondence: nick.nauslar@noaa.gov
}

Received: 15 April 2018; Accepted: 5 June 2018; Published: 9 June 2018

\begin{abstract}
Two extreme wind-driven wildfire events impacted California in late 2017, leading to 46 fatalities and thousands of structures lost. This study characterizes the meteorological and climatological factors that drove and enabled these wildfire events and quantifies their rarity over the observational record. Both events featured key fire-weather metrics that were unprecedented in the observational record that followed a sequence of climatic conditions that enhanced fine fuel abundance and fuel availability. The North Bay fires of October 2017 occurred coincident with strong downslope winds, with a majority of burned area occurring within the first $12 \mathrm{~h}$ of ignition. By contrast, the southern California fires of December 2017 occurred during the longest Santa Ana wind event on record, resulting in the largest wildfire in California's modern history. Both fire events occurred following an exceptionally wet winter that was preceded by a severe four-year drought. Fuels were further preconditioned by the warmest summer and autumn on record in northern and southern California, respectively. Finally, delayed onset of autumn precipitation allowed for critically low dead fuel moistures leading up to the wind events. Fire weather conditions were well forecast several days prior to the fire. However, the rarity of fire-weather conditions that occurred near populated regions, along with other societal factors such as limited evacuation protocols and limited wildfire preparedness in communities outside of the traditional wildland urban interface were key contributors to the widespread wildfire impacts.
\end{abstract}

Keywords: fire weather; fire climate; large wildfires; downslope windstorm; wildland urban interface; drought; foehn winds; Santa Ana winds; Diablo winds

\section{Introduction}

California's fire history is littered with fast-moving, destructive wildfires adjacent to populated areas [1,2]. Many wind-driven fires that occur in the coastal ranges of California burn across steep terrain with fuels shaped by a Mediterranean climate during periods of strong foehn winds in early autumn when fuels remain dry prior to the onset of cool-season precipitation [3,4]. The coincidence of land development in areas prone to wind driven extreme fire weather (i.e., Diablo winds [5], Santa Ana winds [6]) results in fire-related hazards for a large number of people [7]. Approximately one-third of Californians reside in the wildland-urban interface (WUI), with overall population living in the WUI expected to increase in the coming decades [8-10].

Large wildfires are not new to California's landscape [11,12], but costs have escalated recently [13] due to the expanding WUI, the legacy of fire exclusion associated with suppression activities, and more favorable climatic conditions for large fires. Previous research has shown that fire exclusion increases fuel loading and the potential for larger fires in forests that have historically had smaller and more frequent 
fire [2]. However, the impacts of fire exclusion in shrublands, such as chaparral ecosystems in California, are more mixed and generally weaker [1,11]. Much of the western US has seen a noted increase in fire activity (e.g., burned area extent, number of large fires) over the past several decades [14] in part due to changes in climatic conditions that favor and facilitate fire in flammability-limited forests [15]. By contrast, trends in fire activity have been more subdued in Mediterranean California ecoregions and across broader southern California [14,16,17]. The reasons behind these diverging trends may be tied to a decrease in reported fire ignitions [17], which are nearly all human-caused [18], as well as anthropogenic activities including land-use, fire policies, and diligent fire suppression [19]. Nonetheless, interannual climate variability does exhibit significant relationships to burned area extent in these regions [3,17,20,21]. Mediterranean ecosystems are intermediate productivity biomes where fire is often not purely fuel-limited or flammability-limited during the fire season [22]. Additionally, such ecosystems in California are largely co-located with sizeable human populations and anthropogenic land use [19], yielding less direct correlations to climate variability than in other areas with a low anthropogenic footprint where wildfire is more directly limited by climate (e.g., fuel-limited or climate-limited) [23].

In 2017, US federal wildland fire suppression costs exceeded \$2.9 billion US dollars making it the costliest fire season on record [24]. More than 4 million hectares (ha) burned in 2017, which is the second most area burned since 1984, and only 40,000 ha below that in 2015 [24]. For context, we note that US burned area statistics include Alaska, which often contributes substantially to annual total burned area. While over 2 million ha burned in Alaska in 2015, just over 260,000 ha burned in Alaska in 2017 thus highlighting the elevated level of fire activity in the contiguous US. The US wildfire season started across the southern Plains in early March but reached its peak in August and September. The national preparedness level, which is a categorical measure of national fire activity and the number of fire suppression resources committed and available, remained at its highest level for 39 consecutive days in 2017 (72 total days) when large conflagrations were found from northern California, into the Pacific Northwest and eastward into Montana coincident with one of the warmest and driest summers in the observational record for much of the region [25,26]. The 2017 fire season culminated with the wind-driven North Bay fires in October and southern California fires in December (Figure 1), both extreme wildfire events [27]. The North Bay fires were reminiscent of the 1964 Hanley Fire in Napa and Sonoma counties and October 1991 Oakland Hills fire due to the rapid spread of wind-driven fires in densely populated areas around the San Francisco Bay Area. The North Bay fires were the deadliest and most destructive wildfires in California's history, with 44 fatalities and nearly 9000 structures lost (Table 1). The southern California fires included the Thomas fire, which was the largest fire in California's modern history (Table 2).
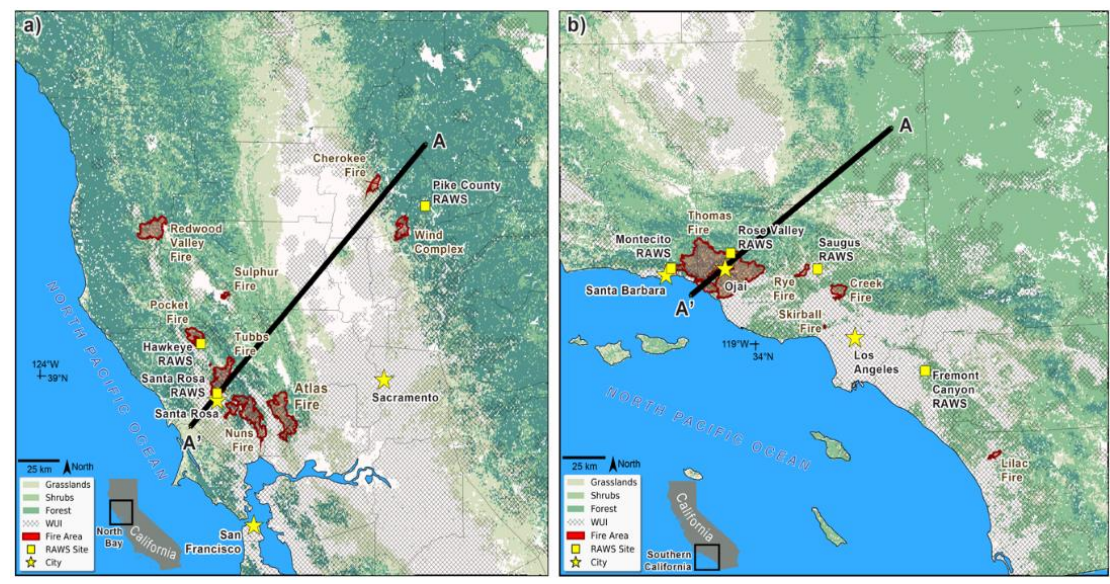

Figure 1. (a) Map of North Bay fires with select Remote Automated Weather Stations (RAWS). Forested areas shaded in green and Wildland Urban Interface (WUI) hatched in grey [28]; (b) Map of southern California fires with select RAWS. Black lines are the vertical cross-section transects for Figures $2 \mathrm{c}$ and $4 \mathrm{c}$. 
Table 1. List of wildfires including wildfire complexes, their final size, the number of structures they destroyed and damaged, and their ignition time during the northern California wildfire event in October 2017. Start times are listed in coordinated universal time (UTC), which is 8 hours ahead of Pacific Standard Time.

\begin{tabular}{lccc}
\hline Names of Wildfires and Complexes & Area Burned (ha) & $\begin{array}{c}\text { Structures } \\
\text { Destroyed/Damaged }\end{array}$ & Start Date and Time (UTC) \\
\hline Tubbs & 14,895 & $5636 / 317$ & 9 October 2017 04:45 \\
\hline Nuns & 22,877 & $1355 / 172$ & 9 October 2017 05:00 \\
\hline Atlas & 20,892 & $120 / 783$ & 9 October 2017 04:52 \\
\hline Pocket & 7024 & $6 / 2$ & 9 October 2017 10:30 \\
\hline $\begin{array}{l}\text { Redwood Valley (Mendocino } \\
\text { Lake Complex) }\end{array}$ & 14,780 & $546 / 44$ & 9 October 2017 06:36 \\
\hline Sulphur (Mendocino Lake Complex) & 893 & $162 / 8$ & 9 October 2017 06:59 \\
\hline Cascade (Wind Complex) & 4042 & $264 / 10$ & 9 October 2017 06:03 \\
\hline LaPorte (Wind Complex) & 2489 & $74 / 2$ & 9 October 2017 07:57 \\
\hline Cherokee & 3406 & $6 / 1$ & 9 October 2017 04:45 \\
\hline
\end{tabular}

Table 2. List of wildfires, their final size, the number of structures they destroyed and damaged, and their ignition time during the southern California wildfire event in December 2017.

\begin{tabular}{lccc}
\hline \multicolumn{1}{c}{ Wildfire Names } & Area Burned (ha) & Structures Destroyed/Damaged & Start Date and Time (UTC) \\
\hline Thomas & 114,078 & $1063 / 280$ & 5 December 2017 02:28 \\
Creek & 6321 & $123 / 81$ & 5 December 2017 11:44 \\
Rye & 2448 & $6 / 3$ & 5 December 2017 19:31 \\
Lilac & 1659 & $157 / 64$ & 7 December 2017 19:15 \\
\hline
\end{tabular}

In this paper, we provide a description of these two extreme fire events, with a particular focus on the roles of weather and climate in enabling and driving these fires. Through a case-study approach, we examined synoptic to meso-scale weather factors coincident to the events as well as climatic conditions antecedent to the events that resulted in exceptional surface fire weather conditions that led to rapid fire growth. We also assessed the rarity of key fire weather indicators during these events relative to the observational record. Finally, we discuss how well each of the events were forecasted from local and national perspectives.

\section{Datasets}

A set of representative long-term (>20 years) surface-based weather observations from Remote Automated Weather Stations (RAWS) proximal to both the North Bay and Southern California fires were selected. RAWS are strategically sited to sample fire weather and fire danger for land management agencies [29]. Weather stations with longer periods of record (e.g., airports) were not utilized in this study due to their locations in valleys usually well away from the stronger downslope winds. Furthermore, observations from regional airports rarely showed strong winds from the northeast quadrant that are characteristic of foehn winds in these regions. RAWS data were quality controlled by removing missing (e.g., -99 or -9999), physically impossible observations (e.g., negative relative humidity), and reviewing the top/bottom 1st percentiles of all observations at each RAWS. Additionally, photos of RAWS sites were examined for any potential micrositing issues (WRCC RAWS). RAWS hourly observations were used to calculate the Fosberg Fire Weather Index (FFWI). FFWI is an instantaneous index that combines the influence of wind speed, temperature, and humidity but does not account for the effect of antecedent conditions in preconditioning fuels. Percentiles of hourly RAWS observations were calculated using the entire period of record for each station.

The Santa Rosa and Hawkeye RAWS were chosen based on their proximity to the Tubbs, Nuns, and Pocket Fires (Figure 1a), their location on the western slopes of the Northern Coastal Ranges (e.g., lee slopes for northeasterly downslope winds), and their long period of record (26 and 24 years, 
respectively). The Atlas Peak RAWS was originally considered due to its proximity to the Atlas Fire and location on crest/western slopes of the Northern Coastal Ranges. However, Atlas Peak RAWS is sheltered by tall trees especially to its north and east, which under samples strong winds from those directions and only had a six-year observational record and was not included in subsequent analysis. The Pike County RAWS was chosen based on its proximity to the Wind Complex, its ridgetop location, and its 25-year observational record. Bangor RAWS was considered, but its observed winds were anomalously weaker than surrounding RAWS during the event, possibly due to its location near the base of small topographic feature and a stand of trees located just to its north [30].

The Montecito and Rose Valley RAWS were chosen based on their proximity to the Thomas Fire (Figure $1 \mathrm{~b}$ ) and their relatively long period of record (21 and 23 years, respectively). The Saugus RAWS was situated between the Rye and Creek Fires (Figure 1b) and had a 22-year period of record. The Fremont Canyon RAWS was selected to demonstrate ridgetop conditions near the southern California coast during the Santa Ana wind event and had a 26-year period of record.

High resolution (2-km) atmospheric model analyses and forecasts from the Weather Research and Forecasting (WRF) model run by California and Nevada Smoke and Air Committee (CANSAC) at the Desert Research Institute was obtained for the North Bay and Southern California events. Model analyses were used to examine both synoptic and meso-scale atmospheric features. For each event we created a cross-section atmospheric profile to visualize finer-scale features of the downslope windstorm including the hydraulic jump and increased surface winds along and near lee slopes.

A chronology of the occurrence of Santa Ana winds was updated from [6] through the end of 2017 (Supplemental Data 1). While many methods have been used to diagnose the occurrence of such winds, including those using station-based observations and mesoscale reanalysis, we chose to use this approach as it uses synoptic-scale drivers (e.g., sea level pressure gradients and upper-level thermal support through cold air advection) that have been linked to widespread strong offshore winds in southwestern California and was readily updated through 2017 to provide a consistent way of examining such data over the past 70 years.

Climate data from two primarily sources were used: (1) monthly temperature and precipitation data from the Parameterized Regression on Independent Slopes Model [31], with data from 1895-2017, and (2) the gridMET daily surface meteorological dataset [32], with data from 1979-2017. The latter dataset was used to calculate 100-h dead fuel moisture using the US National Fire Danger Rating System. Both datasets provide gridded data at a 1/24th degree resolution.

Fire data including ignition time, area burned, daily progression info, and structures destroyed or damaged for the North Bay and Southern California events was obtained from CAL FIRE [33]. Historical California fire information was also obtained from CAL FIRE [34,35].

The National Weather Service (NWS) issues Red Flag Warnings to alert land management agencies to the potential for widespread new ignitions or control problems with existing fires when the combination of fuels and weather conditions support extreme fire danger and/or fire behavior in the next $48 \mathrm{~h}$ [36]. Fire Weather Watches are issued 18-96 h in advance indicating the potential for Red Flag conditions. Local NWS weather forecast offices are responsible for issuing Red Flag Warnings and Fire Weather Watches while the NWS Storm Prediction Center (SPC) issues national daily fire weather outlooks for elevated, critical, and extremely critical fire weather conditions. Critical (extremely) fire weather conditions in California are defined as sustained winds of at least $8.9 \mathrm{~ms}^{-1}\left(13.4 \mathrm{~ms}^{-1}\right), \mathrm{RH}$ below $15 \%(5 \%)$, temperatures above $15.6{ }^{\circ} \mathrm{C}\left(21.1^{\circ} \mathrm{C}\right)$ for three consecutive hours with dry (very dry) fuels. Red Flag Warning criteria generally agree with SPC critical fire weather criteria across the US, but there are differences in the specific criteria used by each NWS forecast office.

\section{Overview of Fire Impacts and Progression}

The North Bay and southern California fires would have been notable in isolation given their size and rapid rate of spread near densely populated areas. However, both events occurred in the same state at the end of a very active US fire season and pushed the bounds of conventional fire wisdom 
with the extreme rates of spread, size, and timing of the fires [27]. The North Bay fires burned nearly $100,000 \mathrm{ha}$, with the majority of these devastating consequences occurring within $12 \mathrm{~h}$ of ignition on 8-9 October 2017 (Table 1), including four of the top 20 deadliest and most destructive wildfires in the state's history. Suppression costs exceeded $\$ 400$ million, $\$ 10$ billion in insurance claims were filed, and overall economic impacts including evacuation and displacement of local residents are estimated to exceed $\$ 85$ billion [37,38]. More than 200,000 people were evacuated during the multi-week fire event in southern California during December 2017. The total costs of the southern California wildfires are still being calculated with current suppression expenditures for the Thomas Fire totaling \$382 million (federal: \$207 million; state: \$175 million) [37], and an estimated \$2.5 billion in insurance claims. The causes for all of the North Bay and southern California fires remain under investigation. However, lightning was not the cause as no cloud-to-ground lightning occurred in vicinity of the wildfires in the preceding 14 days according to Vaisala's National Lighting Detection Network.

\subsection{North Bay Fires}

The North Bay Fires were an outbreak of wildfires that occurred across the Northern Coast Ranges and foothills of the northern Sierra Nevada in northern California (Figure 1a). These areas are characterized by a Mediterranean climate, fine and flashy fuels, such as shrubs and annual grasses, with some trees, and steep terrain [24]. Most of the wildfires, including all of the large fires, ignited during a six-hour period (04:45-10:30 UTC 9 October) and spread rapidly overnight to the southwest coincident with the easterly wind event, known as Diablo winds near the San Francisco Bay Area and Northeast Foehn winds along the western slopes of the Sierra Nevada (Figure 1; Table 1). The rapid spread of these wildfires combined with nighttime ignition and proximity and progression toward populated areas created an exceptional wildfire hazard. The majority of the fatalities, damages, and burned area occurred during the overnight and morning hours of 8-9 October.

The Tubbs Fire was not the largest wildfire during this event but was the most destructive as it moved downslope into the city of Santa Rosa, California and surrounding communities (Figure 1a; Table 1). Embers lofted by strong winds ahead of the flaming front ignited spot fires, including embers that directly landed on or inside homes within suburban communities further complicating suppression and evacuation efforts [39]. By the time the Tubbs fire was contained, it was the most destructive (5636 structures) and second deadliest (22 deaths) wildfire in California's history [33]. The Nuns Fire burned in eastern Sonoma County affecting the Sonoma, Glen Ellen, and Kernwood communities while burning 22,877 ha and destroying 1355 structures (Figure 1a; Table 1). The Atlas Fire burned 20,892 ha and destroyed 783 structures east and north of Napa (Figure 1a; Table 1). Further to the north, the Mendocino-Lake Complex burned more than 15,000 ha and destroyed more than 700 structures while on the western slopes of the Sierra Nevada, the Wind Complex and Cherokee Fires burned nearly 10,000 ha and destroyed nearly 350 structures (Figure 1a; Table 1).

\subsection{Southern California Fires}

An extended period of Santa Ana Winds in December 2017 drove several large wildfires westward and southward across the slopes of the Transverse Ranges of southern California (Figure 1b). Similar to the North Bay Fires, the combination of strong downslope winds, fine and flashy fuels, steep terrain, and the proximity of the wildfires to densely populated areas created a dangerous situation. The Thomas Fire burned 114,078 ha in southwestern California and the time of this writing was the largest wildfire in the state's modern history (Table 2). The Thomas Fire started at 02:28 UTC 5 December 2017 in Ventura County southeast of Ojai and burned more than 40,000 ha within 48 h of ignition spreading generally to the west (Figure 1b). The Thomas Fire grew more than 25,000 ha on two separate days (4-5 December and 9-10 December) and 4000 ha on eight separate days including two days (13-14 December and 15-16 December) that were more than a week after its ignition. The Thomas fire destroyed 1063 structures and directly resulted in two fatalities and was not fully contained until 12 January 2018. Other recent Santa Ana Wind driven fire events, such as those that occurred in October 
2003 and 2007, directly caused more deaths and destruction. However, the flooding and post-fire debris flow triggered by a landfalling atmospheric river [40] over the Thomas Fire burn scar that occurred in Montecito and Santa Barbara claimed at least another 21 lives and destroyed more than 100 homes [41].

A handful of other large wildfires occurred during the prolonged offshore wind event across southern California in December. The Creek and Rye Fires began the morning of 5 December in northwestern Los Angeles County and burned 6321 and 2448 ha, respectively (Figure 1b; Table 2). The Lilac Fire began at 19:15 UTC 7 December in northern San Diego County burning 1659 ha and destroying 157 structures. Outside of the Thomas Fire, wildfires burned more than 10,500 ha, destroyed more than 300 structures, and damaged more than 160 structures across southern California

\section{Meteorological Conditions}

\subsection{North Bay Fire Weather}

The synoptic conditions leading to the North Bay fires featured a rapidly southeastward moving mid-tropospheric shortwave trough that moved through the inland Pacific Northwest and Intermountain West during 8-9 October 2017 (Figure 2a). Behind this positively tilted shortwave mid-tropospheric trough, heights raised aloft over the West Coast and strong northeasterly flow developed across the Sierra Nevada and Northern Coastal Ranges of California (Figure 2a,b). An unusually warm and dry air mass prevailed across most of northern California in the days before the event including Napa County, which experienced temperatures $3-4{ }^{\circ} \mathrm{C}$ above and $\mathrm{RH} 15-20 \%$ below climatological averages per gridMET data [32]. Strong cross-mountain northeasterly flow was apparent between the surface and $800 \mathrm{hPa}(\sim 2000 \mathrm{~m})$ and multiple inversions and critical layers existed below $2000 \mathrm{~m}$, which created a conducive environment for downslope windstorms (Figure $2 \mathrm{~b}, \mathrm{c}$ and Figure 3) [42,43]. The downslope windstorm caused further atmospheric drying as evident by the daily low record for precipitable water $(5.83 \mathrm{~mm}$, lowest since 1948) observed in the Oakland, California 12:00 UTC 9 October atmospheric sounding (Figure 3) and widespread RH values below $20 \%$ (Figure 2 b).

Northeasterly surface winds accelerated during the afternoon to early morning on 8-9 October across much of the region, coincident with a decline in RH (Figure 2b). Consistent with downslope windstorms, the strongest winds and downward motion (Figure 2c; positive values; color-shaded red) were observed near ridge tops and lee slopes with a standing wave feature resolved in potential temperature fields from high-resolution mesoscale modeling forecasts (Figure 2b,c). Across northern California, widespread wind gusts of $15-20 \mathrm{~ms}^{-1}$ with $\mathrm{RH}$ below $15 \%$ were observed from the afternoon of 8 October to morning of 9 October. The Santa Rosa RAWS at 11:00 UTC 9 October reported a temperature of $32.8^{\circ} \mathrm{C}, \mathrm{RH}$ of $7 \%$, E-NE wind gust of $27.3 \mathrm{~ms}^{-1}$, Fosberg Fire Weather Index (FFWI) of 78 , and 10-h dead fuel moisture (FM10) of $12.8 \%$ (Table 3). Similar observations of low humidity and FM10 accompanying high winds and FFWI were found at other stations (Table 3). These values of wind gusts, RH, FM10, or FFWI were typically in the bottom or top 1st percentiles for station hourly observations for the 20+ year observational record (Table 3). When these four near surface meteorological variables were considered jointly during the North Bay Fires, we found at least four consecutive hours (all occurring between 04:00-12:00 UTC 9 October) during which Santa Rosa and Hawkeye RAWS had $>99$ th percentile wind speed/gusts and FFWI, as well as $<2$ nd percentile RH. The duration of such extremes jointly observed across these variables was unprecedented in each station's period of record. As remarkable was that these conditions occurred at night. The strong winds and adiabatic compression associated with the downslope flow and mixing inhibited radiative cooling and nocturnal RH recovery. Such conditions were also seen at Pike County Lookout RAWS but were not unprecedented as seen during two prior occasions in the observational record. 
a)

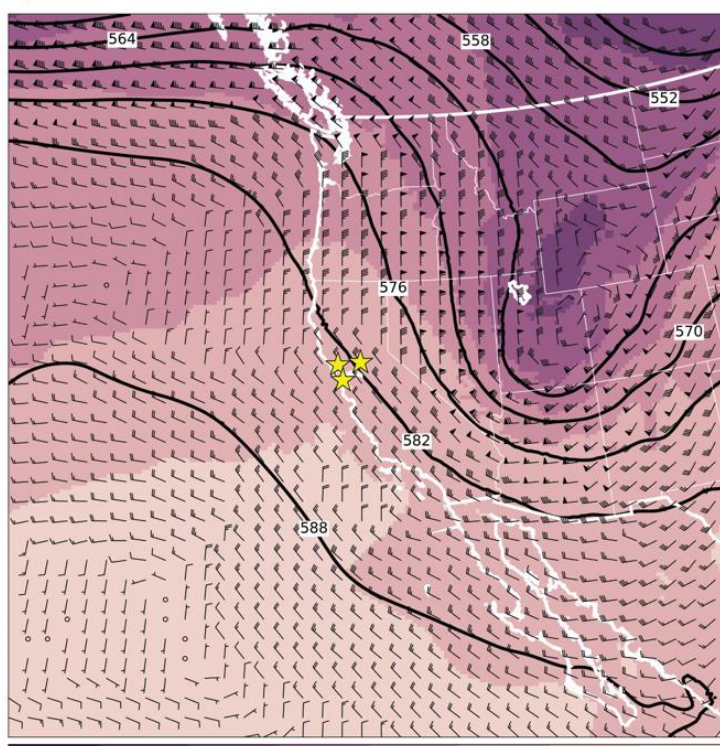

\begin{tabular}{llllllll}
\hline-40 to -35 & -35 to -30 & -30 to -25 & -25 to -20 & -20 to -15 & -15 to -10 & -10 to -5 & $-5+$
\end{tabular}

c) b)

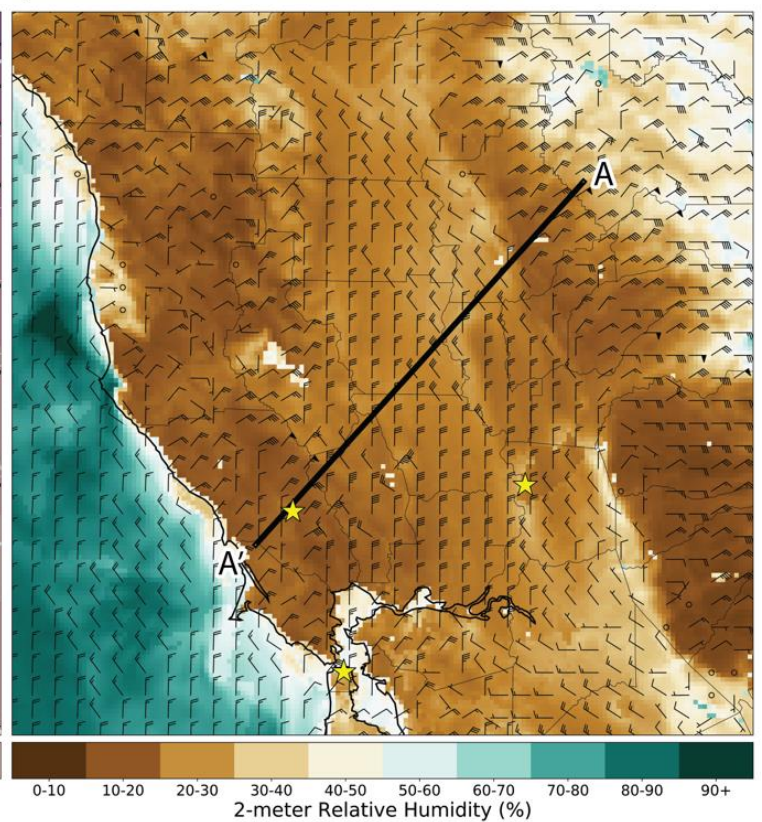

Vertical Cross Section

09 October 2017 @ 09 UTC

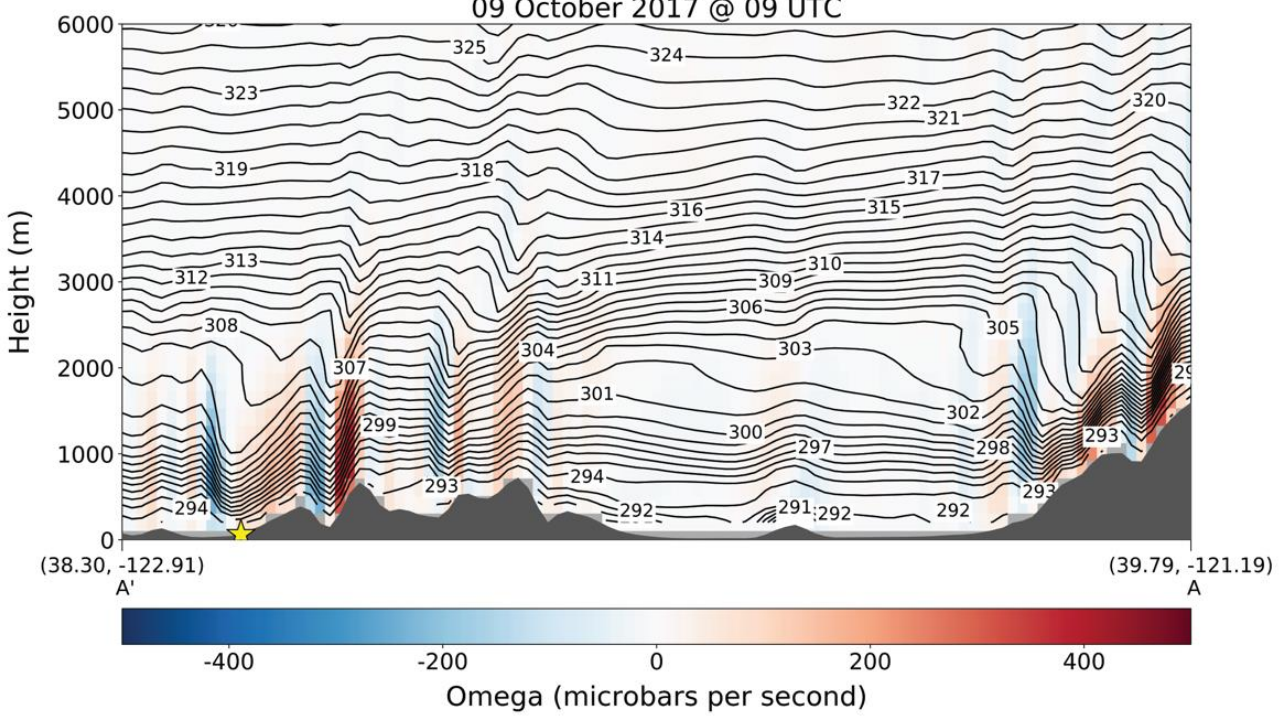

Figure 2. California and Nevada Smoke and Air Committee (CANSAC [44]) 2-km Weather Research and Forecasting Model (WRF) output valid at 09:00 UTC 9 October 2017 (a) 500 hPa heights (dm) contoured, winds (barbs; MPH), temperature (color filled), and yellow stars representing three cities on Figures 1a and 2b (San Francisco, Santa Rosa, Sacramento); (b) surface relative humidity (color filled; \%), winds (barbs; MPH), cross-section transect (same as Figure 1a), and yellow stars representing three cities on Figures 1a and 2a (San Francisco, Santa Rosa, Sacramento); (c) vertical cross section with potential temperature (contoured, K); omega (color filled; $\mu \mathrm{bars} \mathrm{s}^{-1}$; positive values (red) represent downward motion), terrain (dark grey), model terrain (light grey), yellow star denoting Santa Rosa, CA, and latitude and longitude in decimal degrees in parentheses of starting and ending points of the cross-section transect. 
a)

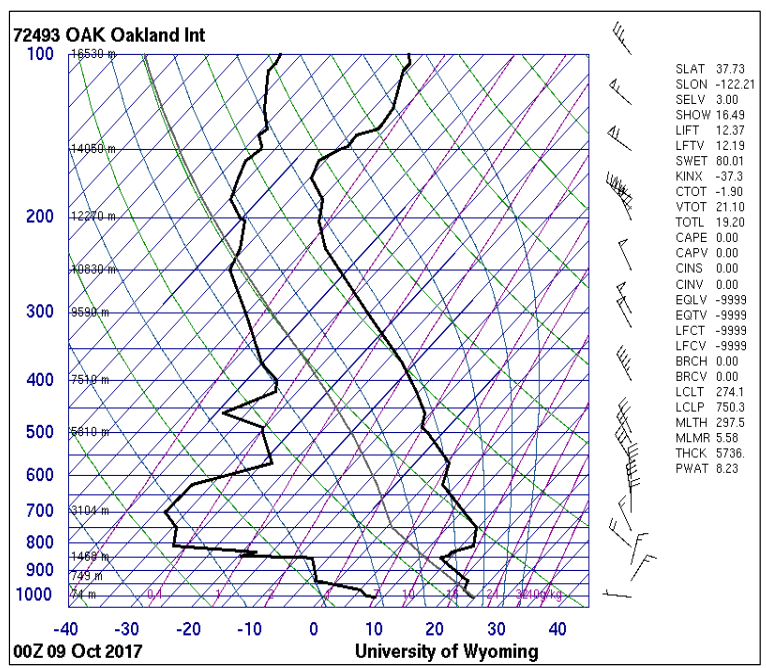

b)

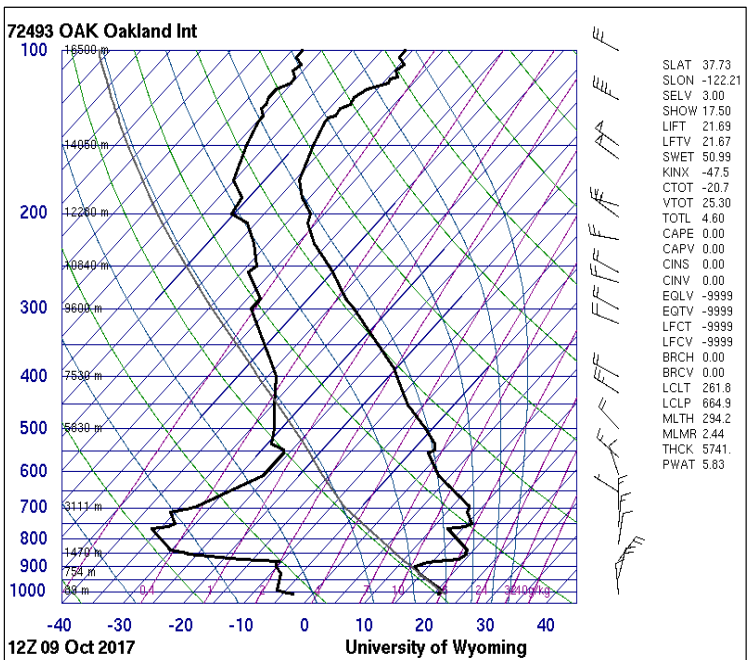

Figure 3. Oakland, California atmospheric soundings at 00:00 UTC (a) and 12:00 UTC (b) 9 October 2017. Precipitable water (PWAT) of $5.83 \mathrm{~mm}$ at 12:00 UTC was a daily low record for the site.

Table 3. Select nearby RAWS hourly observations (Figure 1a) during the peak of critical fire weather conditions during the North Bay fires. Fosberg Fire Weather Index (FFWI), surface relative humidity, surface wind gust, surface wind speed, and 10-h fuel moisture values, percentiles, and any records shown.

\begin{tabular}{lccc}
\hline & Santa Rosa RAWS & Hawkeye RAWS & Pike County Lookout RAWS \\
\hline FFWI/Percentile & $78 / 99$ th & $128 /(\mathrm{MAX})$ & $77 / 99$ th \\
\hline Surface Relative Humidity/Percentile & $7 \% / 1 \mathrm{st}$ & $12 \% / 2 \mathrm{nd}$ & $17 \% / 2 \mathrm{nd}$ \\
\hline Surface Wind Gust/Percentile & $27.3 \mathrm{~ms}^{-1} / 99$ th & $35.3 \mathrm{~ms}^{-1} / 99$ th & $21.9 \mathrm{~ms}^{-1} / 99$ th \\
\hline Surface Wind/Percentile & $11.6 \mathrm{~ms}^{-1} / 99$ th & $21.5 \mathrm{~ms}^{-1} / 99$ th & $13.9 \mathrm{~ms}^{-1} / 99$ th \\
\hline 10-h Fuel Moisture/Percentile & $12.8 \% / 5$ th & $3.8 \% / 5$ th & $5.4 \% / 9$ th \\
\hline Observation Time (UTC) & $11: 009$ October & $07: 009$ October & $12: 009$ October \\
\hline Period of Record (Month/Year) & $01 / 1992-10 / 2017$ & $01 / 1994-10 / 2017$ & $01 / 1992-10 / 2017$ \\
\hline
\end{tabular}

Fire weather conditions were well forecasted by the NWS up to a week prior to the event. The NWS San Francisco/Monterey Bay forecast office first mentioned the possibility of offshore flow with low RH for the weekend (8-9 October 2017) in its fire weather forecast on 2 October 2017, and Storm Prediction Center (SPC) first mentioned the possibility of critical fire weather conditions due to offshore flow and low RH for northern California on 3 October 2017. The NWS San Francisco/Monterey Bay issued a Fire Weather Watch on 5 October valid Sunday morning through Monday morning (8-9 October) with forecast wind gusts up to $25 \mathrm{~ms}^{-1}$ and stated this was the strongest offshore wind event of the fall to date. The watch was later upgraded to a Red Flag Warning on 6 October valid from 18:00 UTC 8 October to 12:00 UTC 10 October for much of the San Francisco Bay Area highlighting low $\mathrm{RH}(5-15 \%)$, strong winds (sustained 6.7-13.4 $\mathrm{ms}^{-1}$, gusts to $25 \mathrm{~ms}^{-1}$ ), and that any wildfire ignition would spread rapidly. Coincidentally, the SPC forecast elevated to critical fire weather conditions for the same areas.

\subsection{Southern California Fire Weather}

This prolonged offshore wind event began as Rossby wave breaking over the interior western US resulted in a mid-tropospheric temperature and height minima that moved south and became cut-off from the larger flow over Arizona while surface high pressure built in over the Great Basin (Figure 4a,b). This feature helped produce northeast flow aloft and at the surface over southern 
California (Figure 4a,b). In addition, the northeast flow aloft led to cold air advection and subsidence across southwestern California that can impart downward momentum and strengthen surface downslope winds. A positively tilted mid-tropospheric ridge slowly moved onshore, centered over the US Pacific coast, with this general pattern persisting until 22 December, keeping offshore flow across southern California (e.g., Figure 4a). Both Santa Ana and Sundowner winds can develop under this synoptic configuration $[6,45,46]$.
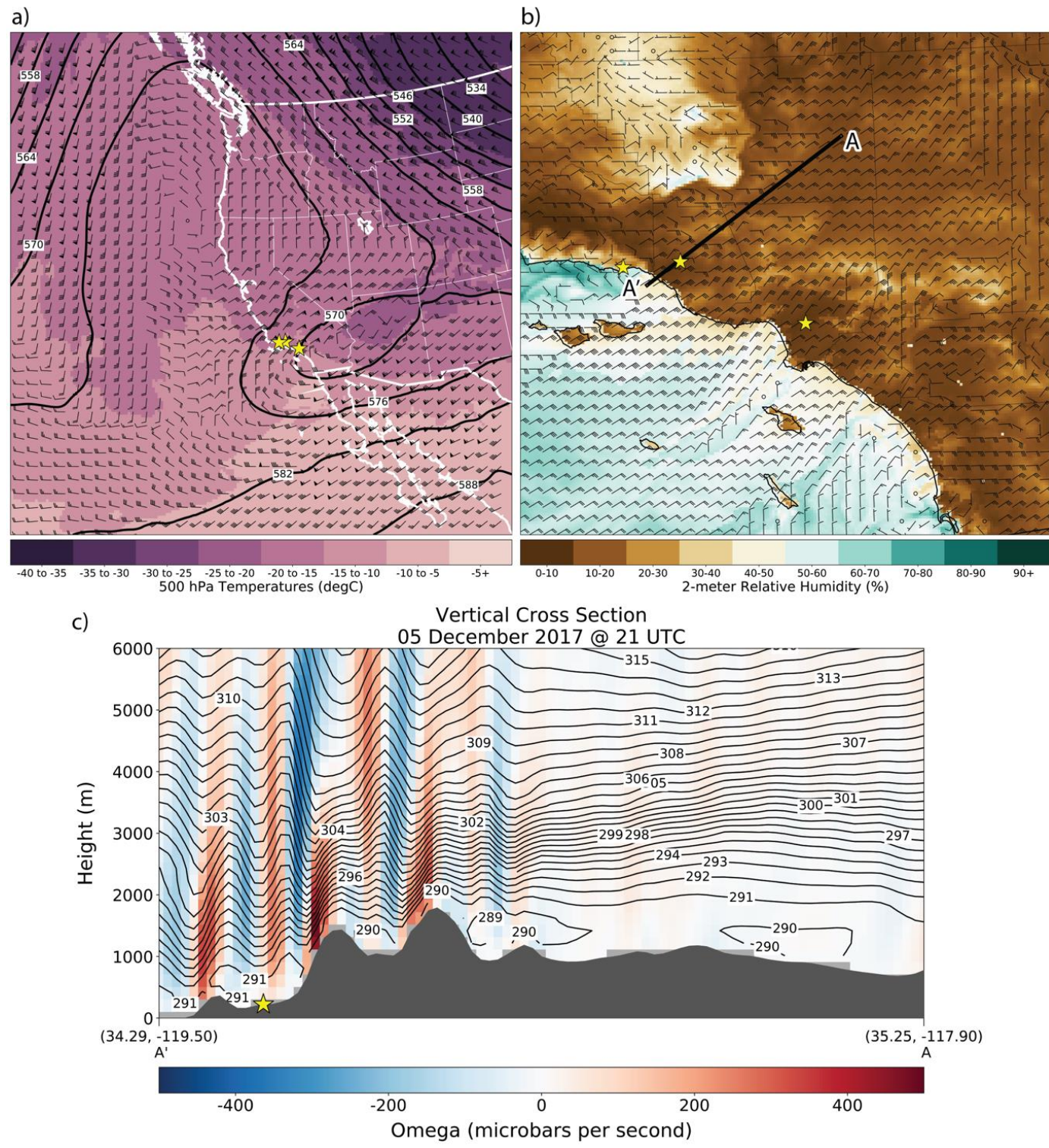

Figure 4. California and Nevada Smoke and Air Committee (CANSAC [44]) 2-km Weather Research and Forecasting Model (WRF) output valid at 21:00 UTC 5 December 2017 (a) 500 hPa heights (dm) contoured, winds (barbs; MPH), temperature (color filled), and yellow stars representing three cities on Figures $1 \mathrm{~b}$ and $4 \mathrm{~b}$ (Santa Barbara, Ojai, Los Angeles); (b) surface relative humidity (color filled; \%), winds (barbs; MPH), cross-section transect, and yellow stars representing three cities on Figures $1 \mathrm{~b}$ and 4a (Santa Barbara, Ojai, Los Angeles) (c): vertical cross section with potential temperature (contoured, $\mathrm{K}$ ); omega (color filled; $\mu$ bars s ${ }^{-1}$; positive values (red) represent downward motion), terrain (dark grey), model terrain (light grey), yellow star denoting Ojai, CA, and latitude and longitude in decimal degrees in parentheses of starting and ending points of the cross-section transect. 
Widespread strong east-northeast surface winds and RH below 15\% developed by 00:00 UTC 5 December and expanded in coverage and intensity by 21:00 UTC 5 December (Figure 4b). The depth and magnitude of the dry air was apparent from local atmospheric soundings including the 12:00 UTC 7 December San Diego, California atmospheric sounding setting a daily record for lowest precipitable water at that location (2.54 mm, since 1948). By 21:00 UTC 5 December, the northerly-easterly winds increased, and RH dropped as strong downward motion developed on the lee slopes across southern California characteristic of a downslope windstorm (Figure $4 b, c)$.

Extreme fire weather conditions were observed across southern California during this Santa Ana wind event. The Saugus RAWS from 17:00-21:00 UTC 5 December observed $>99$ th percentile values for FFWI, wind gust maximum, and wind speed with RH in the 4th percentile. At Fremont Canyon RAWS, $>99$ th percentile values for FFWI, wind gust maximum, and wind speed with RH in the 2nd percentile was observed from 16:00-18:00 UTC 7 December. Up the coast, the Montecito RAWS recorded its lowest $\mathrm{RH}$ ever $(1.0 \%$, although we note that $\mathrm{RH}$ estimates are prone to errors at very low levels of ambient humidity [47]) at 09:00 UTC 12 December with $6.7 \mathrm{~ms}^{-1}$ northerly winds, and >99th percentile values for FFWI, wind gust maximum, and wind speed from 11:00-12:00 UTC 16 December. Shortly after these observations, the Montecito RAWS was burned over by the Thomas Fire. The longevity of key surface fire weather extremes was particularly notable, with a majority of the hours from 08:00 UTC 3 December to 08:00 UTC 19 December having RH below the 5th percentile, indicative of the lack of overnight RH recovery throughout the duration of the event (Table 4). Per the criteria established by [6] which used reanalysis data, Santa Ana wind conditions occurred for 12 consecutive days, 4-15 December, the longest duration event (i.e., consecutive days) in the observational record based on this chronology dating back to 1948. The previous longest Santa Ana wind event in this dataset was nine consecutive days (5-13 February 2006).

Table 4. Percentage of total hours between 08:00 UTC 3 December and 08:00 UTC 19 December 2017 above the 95th (99th) percentile for Fosberg Fire Weather Index (FFWI), surface wind gust, and surface wind speed and below the 5 th (1st) for surface relative humidity and 10-h fuel moisture for select RAWS.

\begin{tabular}{lcccc}
\hline & Saugus RAWS & $\begin{array}{c}\text { Fremont Canyon } \\
\text { RAWS }\end{array}$ & $\begin{array}{c}\text { Rose Valley } \\
\text { RAWS }\end{array}$ & Montecito RAWS \\
\hline FFWI & $22.2 \%(5.5 \%)$ & $57.1 \%(13.0 \%$ & $8.3 \%(3.0 \%)$ & $3.4 \%(0 \%)$ \\
Surface Relative Humidity & $66.8 \%(25.2 \%)$ & $67.0 \%(12.5 \%)$ & $39.6 \%(12.2 \%)$ & $80.4 \%(62.1 \%)$ \\
Surface Wind Gust & $12.7 \%(0 \%)$ & $38.2 \%(0 \%)$ & $10.5 \%(0.6 \%)$ & $0.9 \%(0.6 \%)$ \\
Surface Wind Speed & $15.2 \%(2.5 \%)$ & $46.3 \%(9.7 \%)$ & $4.2 \%(1.1 \%)$ & $1.2 \%(0 \%)$ \\
10-h Fuel Moisture & $0 \%(0 \%)$ & $55.4 \%(22.2 \%)$ & $46.0 \%(12.7 \%)$ & N/A \\
Period of Record (Month/Year) & $01 / 1995-12 / 2017$ & $01 / 1992-12 / 2017$ & $01 / 1994-12 / 2017$ & $01 / 1997-12 / 2017$ \\
\hline
\end{tabular}

The offshore wind event was well forecast by the NWS, up to a week prior to the onset of offshore winds. On 28 November, the NWS Oxnard/Los Angeles forecast office mentioned the possibility of offshore winds for the following week, and on 30 November, SPC forecasted probabilities of critical fire weather conditions across southern California for the following week. By the afternoon of 1 December, a Fire Weather Watch was issued for Santa Barbara, Ventura, and Los Angeles counties for a moderate-to-strong prolonged offshore wind event and was subsequently upgraded to a Red Flag Warning by the next afternoon (2 December). Through the event, at least one Red Flag Warning was valid per day in southern California from 2-21 December, and SPC forecasted critical fire weather conditions consistently through the event including the peak (4-9 December).

\section{Climatic Basis}

The sequence of moisture availability in the years to months preceding these ignitions primed these landscapes for the extreme fire weather and conflagrations that ensued. California hydroclimate is highly variable due to its location along the southernmost extent of the North Pacific jet stream and propensity to receive much of its annual precipitation in a few heavy events [48]. Prior to water year 
2017 (October 2016-September 2017), California endured the drought of observational record from water years 2012-2016, and one of the most extreme multi-annual droughts in 1200 years [49], due to chronic below normal precipitation and exceptionally high rates of potential evapotranspiration associated with the warmest years in the observational record [50]. This chronic drought resulted in large scale loss of tree canopy water [51] and tree mortality across the Sierra Nevada. By contrast, the 2017 water year delivered well above normal to record precipitation across much of the state, with parts of the central to northern Sierra Nevada, and scattered locations near the San Francisco Bay Area receiving the most October-April precipitation since 1895 (Figure 5a). Southern California also generally had October-April precipitation in the top tercile of historical conditions. However, much of this precipitation occurred in fall and winter as the region had a dry spring (March-May).

The above-normal moisture across California during the winter of 2016-2017 resulted in an anomalously productive landscape by spring 2017. Increased moisture content and biomass productivity in semi-arid regions often help promote fire in fuel-limited fire regimes through the accumulation of fine fuels that facilitate fire spread [52]. Previous climate-fire relationships have shown a weak positive correlation between early winter precipitation and burned area during the subsequent fire season in non-forested areas of southern California [20] and cumulative precipitation in several recent winters [3].

Little precipitation fell across California from May 2017 through the remainder of the calendar year. Dry summers are typical in California's Mediterranean climate, but the arrival of autumn precipitation was substantially delayed across the region. September-December precipitation was exceptionally low across the state, and the lowest in over 120 years across portions of south coastal California (Figure 5b). Complementary to below normal precipitation, the region experienced exceptionally warm temperatures with much of northern and central California having their warmest May-September since 1895 (Figure 5c), while much of south coastal California had its warmest October-December since 1895 (Figure 5d). Precipitation from March-December 2017 across portions of southwestern California was the lowest since 1895 . The delayed arrival of wetting precipitation $(>2.5 \mathrm{~mm})$ was particularly notable across southern California near the Thomas Fire. The second longest dry spell on record ( 246 days) was observed at a long-term ( $>60$ years, $<1 \%$ of missing data) National Weather Service Cooperative Observer Network station near the Thomas Fire in Ojai, with precipitation occurring in early January 2018 associated with the post-fire debris flow.

Relationships between interannual variability in temperature and burned area in non-forested coastal Mediterranean ecosystems in California are generally weak [17], as they not typically flammability-limited (but see [21]), yet do show a slight positive correlation with late summer to early fall temperature [20]. The nominal precipitation that occurs during summer in southern California is uncorrelated with historical burned area [20], although precipitation during the month of fire activity is negatively correlated with the sizes of Santa Ana driven fires [3].

The delayed arrival of autumn precipitation and continued warm temperatures leading up to the fire events allowed for dead fuel moistures to remain at levels more commonly found in mid-to-late summer. Climate variables like temperature and precipitation often help inform the ways in which climate variability enables fire. However, metrics calculated from climate and weather variables that are directly designed to represent biophysical processes such as vegetation desiccation (e.g., fuel moistures) and plant water use (e.g., actual evapotranspiration) often are superior correlates of burned area $[20,53]$. We provide two snapshots of 100-h dead fuel moisture percentiles coincident with the North Bay fires on 9 October 2017, and the southern California fires on 8 December 2017. In both cases, a large swath of exceptionally low 100-h dead fuel moisture was co-located with the region of peak fire activity. On 9 October, much of the Bay Area, and southern Sacramento valley experienced fuel moistures below the historical 1\% values (pooled over all calendar days of the year) (Figure 6a). A companion time series of 100-h dead fuel moisture near the Atlas fire shows that conditions below the 3rd percentile for much of the early half of October (Figure $6 c$ ). Similarly, much of coastal southern California experienced 100-h dead fuel moisture in the bottom 1-3\% in early December 2017 (Figure 6b), 
with exceptionally low fuel moistures during the period of peak fire activity including reaching its lowest value in the observational record (1979-2017) (Figure 6d).

a) Oct 16 - Apr 17 Precipitation

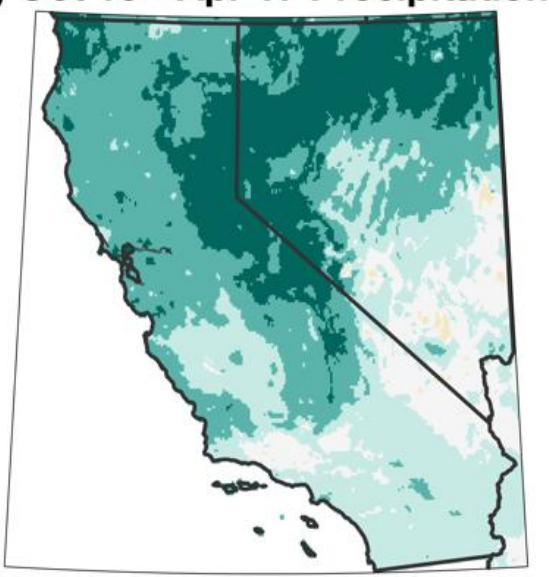

c) May-Sep 17 Temperature

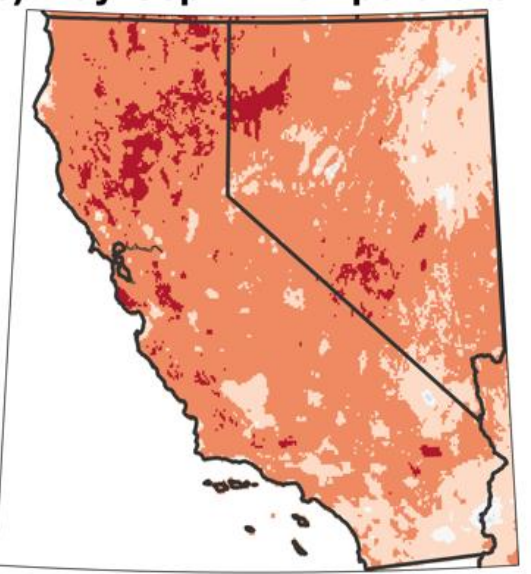

\section{b) Sep-Dec 17 Precipitation}

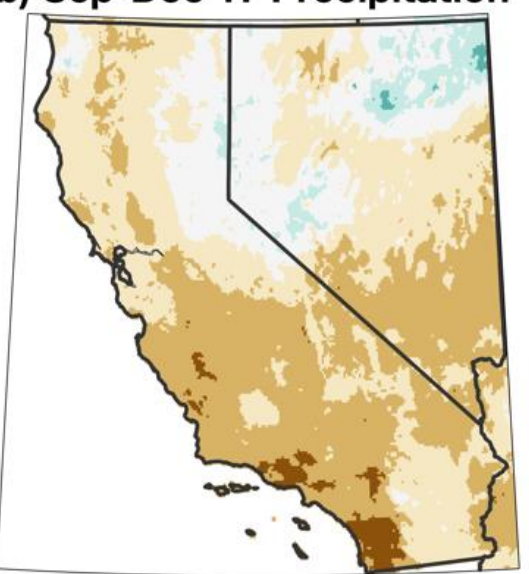

d) Oct-Dec 17 Temperature

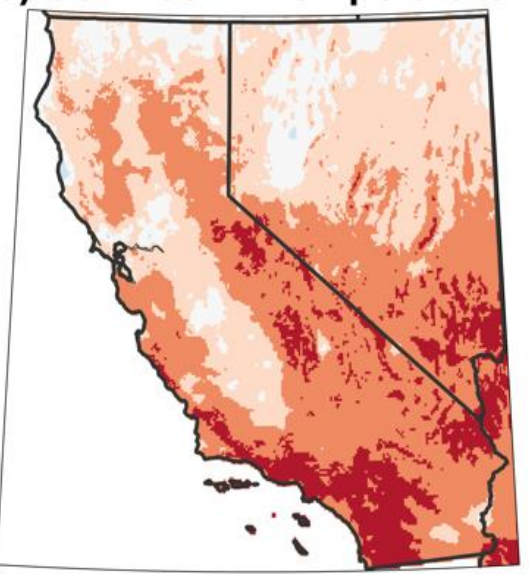

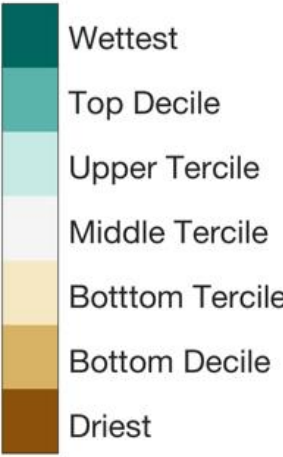

Warmest

Top Decile

Upper Tercile

Middle Tercile

Botttom Tercile

Bottom Decile

Coldest

Figure 5. Classified ranking of (a) October 2016-April 2017 cumulative precipitation; (b) September-December 2017 cumulative precipitation; (c) May-September 2017 mean temperature; and (d) October-December 2017 for the period 1895-2017.
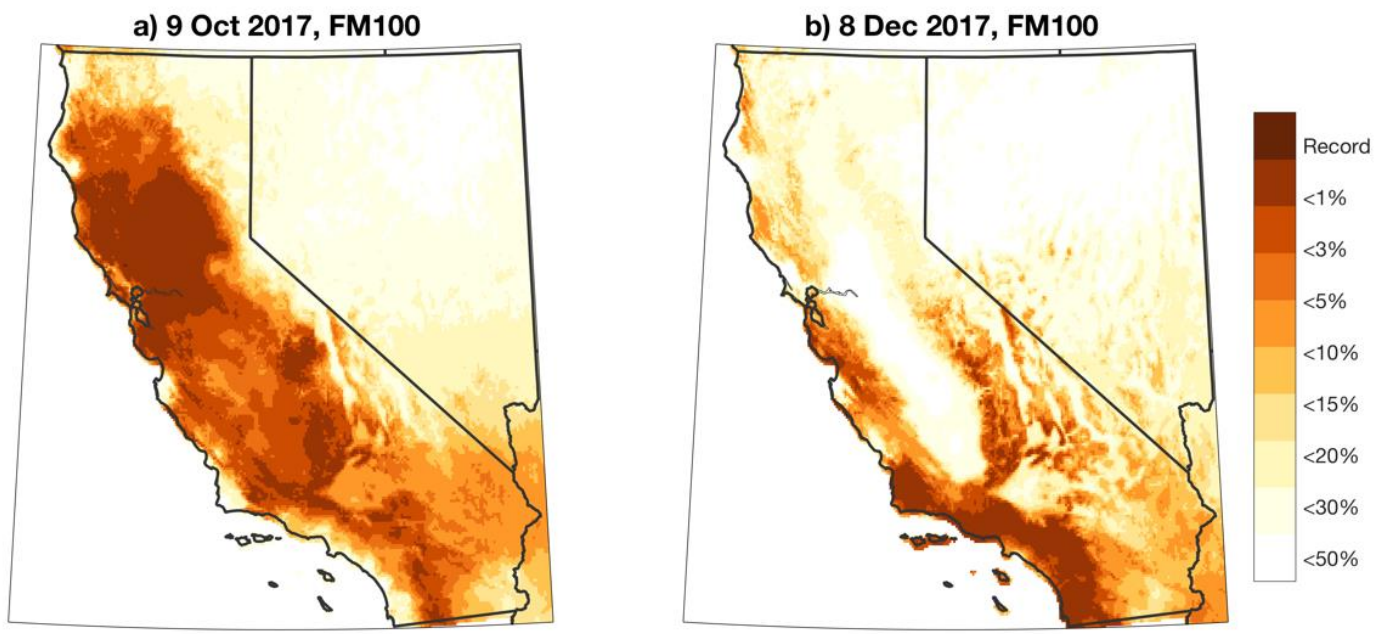

Figure 6. Cont. 
c) $\mathrm{FM} 100\left(38.40^{\circ} \mathrm{N}, 122.24^{\circ} \mathrm{W}\right)$

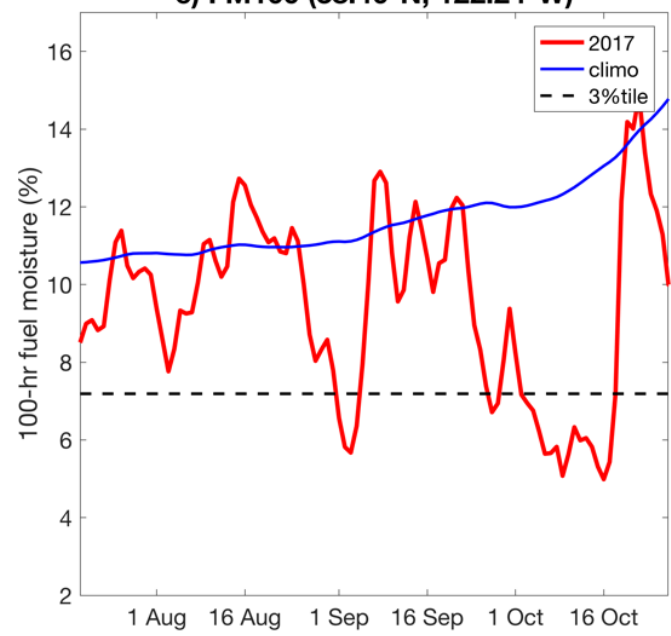

d) $\mathrm{FM} 100\left(34.43^{\circ} \mathrm{N}, 119.10^{\circ} \mathrm{W}\right)$

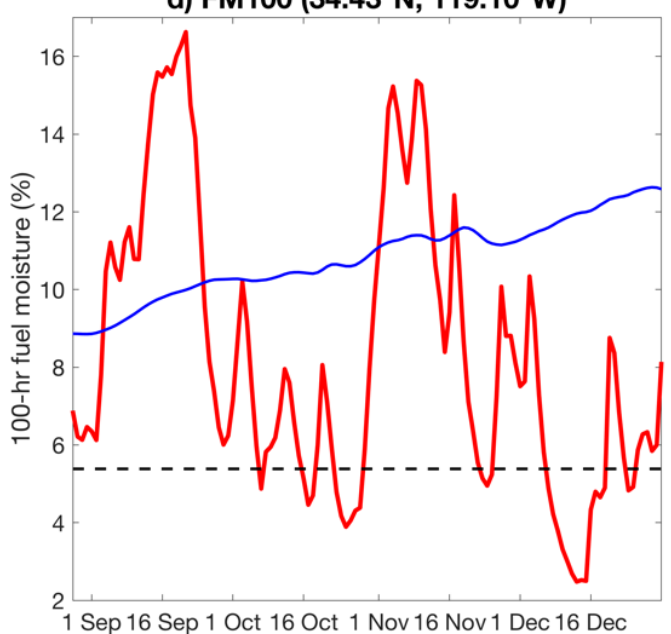

Figure 6. Maps of 100-h dead fuel moisture percentiles for (a) 9 October 2017 and (b) 8 December 2017. Percentiles are calculated relative to data pooled over the calendar year from 1979-2015. Time series of 100 -h fuel moisture near the (c) Atlas fire $\left(38.4^{\circ} \mathrm{N}, 122.24^{\circ} \mathrm{W}\right)$ and $(\mathrm{d})$ Thomas fire $\left(34.43^{\circ} \mathrm{N}, 119.1^{\circ} \mathrm{W}\right)$ prior to and throughout the duration of the fire. The blue line shows 1981-2010 daily average fuel moisture levels, and the dashed horizontal line shows 3rd percentile conditions using data pooled over the calendar year that delineates extreme fire danger.

\section{Summary and Conclusions}

The North Bay and southern California fires were wind-driven conflagrations that affected densely populated areas on the heels of an extended hot and dry period that followed an anomalous wet winter. The sequencing of climatological and meteorological conditions for these fire events mirrors other notable fires of record in California [2,54] and other portions of the world [55]. This highlights the important roles that both climate variability and meteorological factors have on extreme fires in terms of preconditioning fuel abundance, flammability, and driving fire spread. Rare conditions were seen across a spectrum of timescales coinciding with these two fire events. From a meteorological perspective, we found that stations near the North Bay fires experienced their most acute fire weather conditions (as viewed through FFWI and combinations of wind speed, RH, FM10, and FFWI) in over two decades of observations (Table 3). Southern California experienced its longest duration Santa Ana wind event in at least 70 years and daily records for atmospheric dryness which led to chronic periods of fire danger (Figures 5 and 6; Table 4). Common to both events was the occurrence of strong winds that have been shown to be a key determinant in large human-caused wildfires [56]. The most severe multi-annual drought (2012-2016) in California in the observational record preceded well above normal to record setting precipitation in the wet season prior to the fires with some areas recording their wettest October-April in 120 years. During both fires, 100-h dead fuel moistures were below the 3rd percentile, including the lowest values in the observational record (1979-2017) with the Thomas Fire (Figures 5 and 6). Such conditions were facilitated by exceptionally warm temperatures in the months preceding the fires, and the driest March-December since 1895 in southern California. We do not attempt to quantify the relative roles of these climatic extremes on the extent or rate of spread of these extreme wildfire events. Additional analyses may help elucidate the complementary role that fuel conditions played in these wind-driven conflagrations.

The nexus of climate, weather, fuels, and terrain drive large wildfire occurrence [57-59], and these factors all contributed to the North Bay and southern California fire events. Foehn winds have been extensively studied with regard to fire weather (e.g., $[1,60])$ and are a recognized critical fire weather pattern [5] that are often referred to in NWS fire weather forecasts. However, the question remains as to whether the risk posed by extreme foehn wind-driven fires is well quantified 
given recent high-impact foehn wind-driven fire events in California, Chile, and Gatlinburg. We demonstrate that novel conditions in the observational record occurred during both fire events. However, emergency management and city planners must prepare (e.g., Firewise USA) and consider planning for extreme fire events beyond those observed or modeled using 90th or 99th percentile observed meteorological conditions.

Beyond limitations posed by the observational record, changes in the fire environment have and are continuing to occur that may further affect fire risk. For example, the continued expansion of WUI into geographic areas where fuels, terrain, and foehn wind events occur may very well incur additional risk for fire impacts. Changes in climate have and will continue to alter certain properties of the fire environment including increasing fuel aridity [15,61] and fewer days with precipitation [62] thereby increasing the frequency of certain ingredients for such fires. It is not currently well resolved how climate change will affect the occurrence or intensity of foehn wind events $[63,64]$. These fires, like many others than occur with foehn winds in California, were anthropogenically ignited. Efforts and policies to reduce powerline-caused ignitions coincident with forecasted wind events may be explored such as re-routing or cutting off power in areas of prone to high winds and burying powerlines in regions particularly prone to downslope windstorms. Further research into the environmental and societal factors of foehn wind-driven fire disasters in the WUI, including events that have occurred in similar locations (e.g., Tubbs and Hanley Fires) would help provide better insight on why these events continue to transpire.

NWS forecasts for these events were accurate and provided lead time to the public and emergency personnel, but the hazards still materialized leading to 46 deaths and thousands of homes destroyed with costs exceeding $\$ 10$ billion. Red Flag Warnings were initially intended for fire and emergency management personnel, and that is still the official NWS directive [36]. However, over time, Red Flag Warnings have been used more to alert the public about dangerous fire weather conditions. Efforts are underway in the NWS to better understand the messaging of Red Flag Warnings to the public and evaluate the Red Flag Warning program. The NWS should continue improving its fire weather program and decision support services to better communicate the risks and impacts associated with its forecasts.

Other preparative or reactionary measures could have helped reduce some of the impacts these fires had on losses including reverse evacuation calls [65], improved public communication [65,66], and better zoning and building codes to withstand spotting embers [67]. Most of the deaths and structures destroyed from these two events occurred in the North Bay, demonstrating the devastating effects of large, fast-moving wildfires moving into urban areas. Given the recent catastrophic wildfires globally (e.g., Fort McMurray, Portugal, Gatlinburg, Chile), co-existing with wildfires and mitigating their effects are of paramount importance [68]. Improving weather and fuels forecasts and the messaging and communication of those forecasts would help mitigate some of the effects of wildfires in the WUI. However, while technological solutions are helpful, fire-related disasters are an amalgamation of societal, political, and economic problems that require a collective set of solutions.

Supplementary Materials: The following are available online at http://www.mdpi.com/2571-6255/1/1/18/s1, Chronology of Santa Ana Wind dates from Abatzoglou et al. 2013

Author Contributions: N.J.N. and J.T.A. designed research; N.J.N., J.T.A., and P.T.M. synthesized, analyzed data, and/or developed figures; and N.J.N. and J.T.A. wrote the paper.

Acknowledgments: The authors would like to thank Benjamin J. Hatchett for his help on revising the figures. J.T.A. was partially supported by the National Science Foundation under award DMS-1520873.

Conflicts of Interest: The authors declare no conflicts of interest.

\section{References}

1. Keeley, J.E.; Fotheringham, C.J.; Moritz, M.A. Lessons from the october 2003. Wildfires in Southern California. J. For. 2004, 102, 26-31. [CrossRef] 
2. Keeley, J.E.; Safford, H.; Fotheringham, C.J.; Franklin, J.; Moritz, M. The 2007 southern California wildfires: Lessons in complexity. J. For. 2009, 107, 287-296.

3. Jin, Y.; Randerson, J.T.; Capps, S.; Hall, A.; Faivre, N.; Goulden, M.L. Contrasting controls on wildland fires in Southern California during periods with and without Santa Ana events. J. Geophys. Res. Biogeosci. 2014, 119, 432-450. [CrossRef]

4. Moritz, M.A.; Moody, T.J.; Krawchuk, M.A.; Hughes, M.; Hall, A. Spatial variation in extreme winds predicts large wildfire locations in chaparral ecosystems. Geophys. Res. Lett. 2010, 37, L04801. [CrossRef]

5. Werth, P.A.; Potter, B.E.; Clements, C.B.; Finney, M.; Goodrick, S.L.; Alexander, M.E.; Cruz, M.G.; Forthofer, J.A.; McAllister, S.S. Synthesis of Knowledge of Extreme Fire Behavior: Volume I for Fire Managers; United States Department of Agriculture: Portland, OR, USA, 2011; Volume PNW-GTR-85.

6. Abatzoglou, J.T.; Barbero, R.; Nauslar, N.J. Diagnosing Santa Ana winds in Southern California with synoptic-scale analysis. Weather Forecast. 2013, 28, 704-710. [CrossRef]

7. Syphard, A.D.; Radeloff, V.C.; Keuler, N.S.; Taylor, R.S.; Hawbaker, T.J.; Stewart, S.I.; Clayton, M.K. Predicting spatial patterns of fire on a southern California landscape. Int. J. Wildl. Fire 2008, 17, 602-613. [CrossRef]

8. Radeloff, V.C.; Hammer, R.B.; Stewart, S.I.; Fried, J.S.; Holcomb, S.S.; McKeefry, J.F. The wildland-urban interface in the United States. Ecol. Appl. 2005, 15, 799-805. [CrossRef]

9. Radeloff, V.C.; Helmers, D.P.; Kramer, H.A.; Mockrin, M.H.; Alexandre, P.M.; Bar-Massada, A.; Butsic, V.; Hawbaker, T.J.; Martinuzzi, S.; Syphard, A.D.; et al. Rapid growth of the US wildland-urban interface raises wildfire risk. Proc. Natl. Acad. Sci. USA 2018. [CrossRef] [PubMed]

10. Hammer, R.B.; Stewart, S.I.; Radeloff, V.C. Demographic trends, the wildland-urban interface, and wildfire management. Soc. Nat. Resour. 2009, 22, 777-782. [CrossRef]

11. Keeley, J.E.; Fotheringham, C.J. Historic fire regime in southern California shrublands. Conserv. Biol. 2001, 15, 1536-1548. [CrossRef]

12. Moritz, M.A. Spatiotemporal analysis of controls of shrubland fire regimes: Age dependency and fire hazard. Ecology 2003, 84, 351-361. [CrossRef]

13. United States Department of Agriculture Forest Service. The Rising Cost of Wildfire Operations: Effects on the Forest Service's Non-Fire Work; 2015. Available online: https:/ /www.fs.fed.us/sites/default/ files /2015Fire-Budget-Report.pdf (accessed on 25 May 2018).

14. Dennison, P.; Brewer, S.; Arnold, J.; Moritz, M. Large wildfire trends in the western United States, $1984-2011$. Geophys. Res. Lett. 2014, 41, 2928-2933. [CrossRef]

15. Abatzoglou, J.T.; Williams, A.P. Impact of anthropogenic climate change on wildfire across western US forests. Proc. Natl. Acad. Sci. USA 2016, 113, 11770-11775. [CrossRef] [PubMed]

16. Syphard, A.D.; Keeley, J.E.; Abatzoglou, J.T. Trends and drivers of fire activity vary across California aridland ecosystems. J. Arid Environ. 2017, 144, 110-122. [CrossRef]

17. Keeley, J.E.; Syphard, A.D. Different historical fire-climate patterns in California. Int. J. Wildl. Fire 2017, 26, 253-268. [CrossRef]

18. Balch, J.K.; Bradley, B.A.; Abatzoglou, J.T.; Nagy, R.C.; Fusco, E.J.; Mahood, A.L. Human-started wildfires expand the fire niche across the United States. Proc. Natl. Acad. Sci. USA 2017, 114, 2946-2951. [CrossRef] [PubMed]

19. Syphard, A.D.; Keeley, J.E.; Pfaff, A.H.; Ferschweiler, K. Human presence diminishes the importance of climate in driving fire activity across the United States. Proc. Natl. Acad. Sci. USA 2017, 114, 13750-13755. [CrossRef] [PubMed]

20. Abatzoglou, J.T.; Kolden, C.A. Relationships between climate and macroscale area burned in the western United States. Int. J. Wildl. Fire 2013, 22, 1003-1020. [CrossRef]

21. Williams, A.P.; Gentine, P.; Moritz, M.A.; Roberts, D.; Abatzoglou, J.T. Effect of reduced summer cloud shading on evaporative demand and wildfire in coastal southern California. Geophys. Res. Lett. 2018. [CrossRef]

22. Pausas, J.G.; Ribeiro, E. The global fire-productivity relationship. Glob. Ecol. Biogeogr. 2013, 22, 728-736. [CrossRef]

23. McKenzie, D.; Littell, J.S. Climate change and the eco-hydrology of fire: Will area burned increase in a warming western U.S.? Ecol. Appl. 2017, 27, 26-36. [CrossRef] [PubMed]

24. National Interagecy Fire Center. Total Wildland Fires and Acres (1960-2017); National Interagecy Fire Center: Boise, ID, USA, 2017. 
25. Abatzoglou, J.T.; McEvoy, D.J.; Redmond, K.T. The West Wide Drought Tracker: Drought Monitoring at Fine Spatial Scales. Bull. Am. Meteorol. Soc. 2017, 98, 1815-1820. [CrossRef]

26. Balch, J.K.; Schoennagel, T.; Williams, A.P.; Abatzoglou, J.T.; Cattau, M.; Mietkiewicz, N.; St. Denis, L. Switching on the big burn of 2017. Fire 2018, 1. [CrossRef]

27. Tedim, F.; Leone, V.; Amraoui, M.; Bouillon, C.; Coughlan, R.M.; Delogu, M.G.; Fernandes, M.P.; Ferreira, C.; McCaffrey, S.; McGee, K.T.; et al. Defining Extreme Wildfire Events: Difficulties, Challenges, and Impacts. Fire 2018, 1. [CrossRef]

28. Homer, C.; Dewitz, J.; Yang, L.; Jin, S.; Danielson, P.; Xian, G.; Coulston, J.; Herold, N.; Wickham, J.; Megown, K. Completion of the 2011 National Land Cover Database for the conterminous United States-Representing a decade of land cover change information. Photogramm. Eng. Remote Sens. 2015, 81, 345-354. [CrossRef]

29. National Interagecy Fire Center. Remote Automated Weather Stations. Available online: https://raws.nifc. gov (accessed on 28 May 2018).

30. Western Regional Climate Center. Bangor RAWS. Available online: https://wrcc.dri.edu/cgi-bin/rawMAIN. pl?caCBGR (accessed on 28 May 2018).

31. Daly, C.; Halbleib, M.; Smith, J.I.; Gibson, W.P.; Doggett, M.K.; Taylor, G.H.; Curtis, J.; Pasteris, P.P. Physiographically sensitive mapping of climatological temperature and precipitation across the conterminous United States. Int. J. Climatol. 2008, 28, 2031-2064. [CrossRef]

32. Abatzoglou, J.T. Development of gridded surface meteorological data for ecological applications and modelling. Int. J. Climatol. 2013, 33, 121-131. [CrossRef]

33. CAL FIRE Incident Information. Available online: http://cdfdata.fire.ca.gov/incidents/ (accessed on 24 February 2018).

34. CAL FIRE Top 20 Deadliest California Wildfires. Available online: http:/ / calfire.ca.gov/communications / downloads/fact_sheets/Top20_Deadliest.pdf (accessed on 24 February 2018).

35. CAL FIRE Top 20 Most Destructive California Wildfires. Available online: http://www.fire.ca.gov/ communications / downloads/fact_sheets/Top20_Destruction.pdf (accessed on 24 February 2018).

36. National Weather Service. National Weather Service Instruction 10-401. Fire Weather Services Product Specification. Available online: http:/ / www.nws.noaa.gov / directives/sym/pd01004001curr.pdf (accessed on 28 May 2018).

37. National Interagecy Coordination Center. Incident Management Situation Report Archives; National Interagency Coordination Center: Boise, ID, USA, 2018. Available online: https:/ /www.predictiveservices.nifc.gov/ intelligence/archive.htm (accessed on 24 May 2018).

38. Kasler, D. Wine country wildfires costs now top \$9 billion, costliest in California's history. The Sacramento Bee 2017.

39. Watkins, D.; Griggs, T.; Lee, J.C.; Park, Haeyoun, S.A.; Wallace, T.; Ward, T. How California's Most Destructive Wildfire Spread, Hour by Hour. Available online: https:/ /www.nytimes.com/interactive/2017/10/21/us/ california-fire-damage-map.html (accessed on 21 February 2018).

40. Oakley, N.S.; Lancaster, J.T.; Kaplan, M.L.; Ralph, F.M. Synoptic conditions associated with cool season post-fire debris flows in the Transverse Ranges of southern California. Nat. Hazards 2017, 88, 327-354. [CrossRef]

41. Livingston, M.; Grad, S. California's Largest on Record, Finally 100\% Contained. Available online: http:/ / www.latimes.com/local/lanow / la-me-thomas-fire-contained-20180112-story.html (accessed on 21 February 2018).

42. Clark, T.L.; Farley, R.D. Severe downslope windstorm calculations in two and three spatial dimensions using anelastic interactive grid nesting: A possible mechanism for gustiness. J. Atmos. Sci. 1984, 41, 329-350. [CrossRef]

43. Smith, R.B. On severe downslope winds. J. Atmos. Sci. 1985, 42, 2597-2603. [CrossRef]

44. CANSAC. CANSAC Model Output. Available online: https:/ / cansac.dri.edu (accessed on 10 February 2018).

45. Hatchett, B.J.; Smith, C.M.; Nauslar, N.J.; Kaplan, M.L. Brief Communication: Synoptic-scale differences between Sundowner and Santa Ana wind regimes in the Santa Ynez Mountains, California. Nat. Hazards Earth Syst. Sci. 2018, 18, 419. [CrossRef]

46. Blier, W. The sundowner winds of Santa Barbara, California. Weather Forecast. 1998, 13, 702-716. [CrossRef]

47. Horel, J.D.; Dong, X. An evaluation of the distribution of Remote Automated Weather Stations (RAWS). J. Appl. Meteorol. Climatol. 2010, 49, 1563-1578. [CrossRef] 
48. Dettinger, M.D.; Ralph, F.M.; Das, T.; Neiman, P.J.; Cayan, D.R. Atmospheric rivers, floods and the water resources of California. Water 2011, 3, 445-478. [CrossRef]

49. Griffin, D.; Anchukaitis, K.J. How unusual is the 2012-2014 California drought? Geophys. Res. Lett. 2014, 41, 9017-9023. [CrossRef]

50. Williams, A.P.; Seager, R.; Abatzoglou, J.T.; Cook, B.I.; Smerdon, J.E.; Cook, E.R. Contribution of anthropogenic warming to California drought during 2012-2014. Geophys. Res. Lett. 2015, 42, 6819-6828. [CrossRef]

51. Asner, G.P.; Brodrick, P.G.; Anderson, C.B.; Vaughn, N.; Knapp, D.E.; Martin, R.E. Progressive forest canopy water loss during the 2012-2015 California drought. Proc. Natl. Acad. Sci. USA 2016, 113, E249-E255. [CrossRef] [PubMed]

52. Littell, J.S.; McKenzie, D.; Peterson, D.L.; Westerling, A.L. Climate and wildfire area burned in western U.S. ecoprovinces, 1916-2003. Ecol. Appl. 2009, 19, 1003-1021. [CrossRef] [PubMed]

53. Littell, J.S.; Peterson, D.L.; Riley, K.L.; Liu, Y.; Luce, C.H. A review of the relationships between drought and forest fire in the United States. Glob. Chang. Biol. 2016, 22, 2352-2369. [CrossRef] [PubMed]

54. Westerling, A.L.; Cayan, D.R.D.; Brown, T.T.J.; Hall, B.L.; Riddle, L.G. Climate, Santa Ana winds and autumn wildfires in southern California. Eos Trans. Am. Geophys. Union 2004, 85, 289-296. [CrossRef]

55. Cruz, M.G.; Sullivan, A.L.; Gould, J.S.; Sims, N.C.; Bannister, A.J.; Hollis, J.J.; Hurley, R.J. Anatomy of a catastrophic wildfire: The Black Saturday Kilmore East fire in Victoria, Australia. For. Ecol. Manag. 2012, 284, 269-285. [CrossRef]

56. Abatzoglou, J.T.; Balch, J.K.; Bradley, B.A.; Kolden, C.A. Human-related ignitions concurrent with high winds promote large wildfires across the USA. Int. J. Wildl. Fire 2018. [CrossRef]

57. Bessie, W.C.; Johnson, E.A. The relative importance of fuels and weather on fire behavior in subalpine forests. Ecology 1995, 76, 747-762. [CrossRef]

58. Bowman, D.M.J.S.; Williamson, G.J.; Abatzoglou, J.T.; Kolden, C.A.; Cochrane, M.A.; Smith, A.M.S. Human exposure and sensitivity to globally extreme wildfire events. Nat. Ecol. Evol. 2017, 1, 58. [CrossRef] [PubMed]

59. Parisien, M.-A.; Moritz, M.A. Environmental controls on the distribution of wildfire at multiple spatial scales. Ecol. Monogr. 2009, 79, 127-154. [CrossRef]

60. Sharples, J.J.; Mills, G.A.; McRae, R.H.D.; Weber, R.O. Foehn-like winds and elevated fire danger conditions in southeastern Australia. J. Appl. Meteorol. Climatol. 2010, 49, 1067-1095. [CrossRef]

61. Westerling, A.; Bryant, B.; Preisler, H. Climate change and growth scenarios for California wildfire. Clim. Chang. 2011. [CrossRef]

62. Polade, S.D.; Pierce, D.W.; Cayan, D.R.; Gershunov, A.; Dettinger, M.D. The key role of dry days in changing regional climate and precipitation regimes. Sci. Rep. 2014, 4, 4364. [CrossRef] [PubMed]

63. Hughes, M.; Hall, A.; Kim, J. Human-induced changes in wind, temperature and relative humidity during Santa Ana events. Clim. Chang. 2011, 109, 119-132. [CrossRef]

64. Miller, N.L.; Schlegel, N.J. Climate change projected fire weather sensitivity: California Santa Ana wind occurrence. Geophys. Res. Lett. 2006, 33. [CrossRef]

65. Velez, A.-L.K.; Diaz, J.M.; Wall, T.U. Public information seeking, place-based risk messaging and wildfire preparedness in southern California. Int. J. Wildl. Fire 2017, 26, 469-477. [CrossRef]

66. Stephens, S.L.; Adams, M.A.; Handmer, J.; Kearns, F.R.; Leicester, B.; Leonard, J.; Moritz, M.A. Urban-wildland fires: How California and other regions of the US can learn from Australia. Environ. Res. Lett. 2009, 4, 14010. [CrossRef]

67. Quarles, S.L.; Valachovic, Y.; Nakamura, G.M.; Nader, G.A.; de Lasaux, M.J. Home Survival in Wildfire-Prone Areas: Building Materials and Design Considerations; ANR Publication 8393; ANR Publication 8393; University of California, Agriculture and Natural Resources: Richmond, CA, USA, 2010; Available online: https: / / escholarship.org/uc/item/4vt8w5qk (accessed on 24 February 2018).

68. Smith, A.M.S.; Kolden, C.A.; Paveglio, T.B.; Cochrane, M.A.; Bowman, D.M.J.S.; Moritz, M.A.; Kliskey, A.D.; Alessa, L.; Hudak, A.T.; Hoffman, C.M.; et al. The Science of Firescapes: Achieving Fire-Resilient Communities. Bioscience 2016, 66, 130-146. [CrossRef] [PubMed] 